INTEGRITAS : Jurnal Pengabdian

Vol 4, No 2, Desember 2020

ISSN 2580 - 7978 (cetak) ISSN 2615 - 0794 (online)

\title{
PENINGKATAN PRODUKTIVITAS MELALUI PELATIHAN KERAJINAN TANGAN DI ERA PANDEMI DESA SUKOLILAN KECAMATAN PATEBON KABUPATEN KENDAL
}

\section{IMPROVEMENT OF PRODUCTIVITY THROUGH TRAINING HAND CRAFTS IN THE ERA OF PANDEMI SUKOLILAN VILLAGE PATEBON KENDAL}

\author{
Dwi Astarani Aslindar ${ }^{1)}$, Utami Puji Lestari ${ }^{2)}$, Mochammad Purnomo ${ }^{3)}$, \\ Ahmad Dwi Nurdiyanto ${ }^{4)}$ \\ ${ }^{1,2,3}$ Fakultas Ekonomika dan Bisnis, Universitas Selamat Sri \\ ${ }^{1}$ Email : dwiastarani@gmail.com
}

\begin{abstract}
Abstrak: Pandemi Covid 19 yang terjadi di Indonesia berdampak pada terhambatnya perekonomian negara. Kondisi ini juga dirasakan oleh kepala keluarga yang secara finansial terhambat bahkan tidak sedikit yang finansialnya harus terhenti. Hal ini dirasakan juga pada kondisi perekonomian rumah tangga penduduk Desa Sukolilan Kecamatan Patebon Kabupaten Kendal. Pelatihan dirasakan perlu oleh tim pengabdian masyarakat Universitas Selamat Sri Kendal yang ditujukan untuk ibu rumah tangga tentang peningkatan produktivitas melalui pelatihan kerajinan tangan di era pandemi. Kegiatan ini diharapkan masyarakat setempat terutama para ibu-ibu rumah tangga Desa Sukolilan Kecamatan Patebon Kabupaten Kendal dapat mengembangkan ilmu yang diberikan untuk memanfaatkan waktu luang dengan kegiatan yang produktif melalui pembuatan kerajinan tangan selama masa pandemi pemerintah menerapkan protokol kesehatan untuk di rumah saja dan dapat dijadikan peluang usaha untuk menambah pendapatan keluarga. Hasil dari kegiatan pelatihan, ibu-ibu rumah tangga memiliki pengetahuan dan keterampilan berwirausaha.
\end{abstract}

Kata Kunci : Produktivitas, Pelatihan, Kerajinan Tangan

Abstract: The Covid 19 pandemic that occurred in Indonesia had an impact on the stagnation of the country's economy. This condition is also felt by the head of the family who is financially hampered, even a few whose finances have to stop. This is also felt in the household economic conditions of residents of Sukolilan Village, Patebon District, Kendal Regency. The training was felt necessary by the Selamat Sri Kendal University community service team aimed at housewives about increasing productivity through handicraft training in the pandemic era. This activity is expected that the local community, especially housewives in Sukolilan Village, Patebon District, Kendal Regency, can develop the knowledge given to take advantage of free time with productive activities through making handicrafts during the pandemic, the government applies health protocols for at home only and can be used as an opportunity. business to increase family income. As a result of the training activities, housewives have entrepreneurial knowledge and skills.

Keywords: Productivity, Training, Hand Crafts 


\section{INTEGRITAS : Jurnal Pengabdian}

Vol 4, No 2, Desember 2020

ISSN 2580 - 7978 (cetak) ISSN 2615 - 0794 (online)

\section{PENDAHULUAN}

Pandemi Covid 19 merupakan kondisi yang harus dialami oleh seluruh negara di dunia tidak terkecuali di Indonesia. Hingga per tanggal 30 Oktober 2020, tercatat sebanyak 406.945 kasus Covid 19 di Indonesia (Gugus Tugas Percepatan Penanganan Covid 19, 2020). Hal ini mendorong pemerintah Indonesia untuk memberlakukan kebijakan menerapkan protokol kesehatan dengan di rumah saja guna mengantisipasi penyebaran Covid 19. Kondisi ini membawa dampak yang cukup serius pada perekonomian Indonesia. Perekonomian Indonesia terhambat yang mengakibatkan pemutusan hubungan kerja (PHK) ataupun pemberhentian sementara tenaga kontrak/honorer (Modjo, 2020). Berdasarkan data Kementerian Ketenagakerjaan (Kemnaker) per 7 April 2020, akibat pandemi Covid 19, tercatat sebanyak 39.977 perusahaan di sektor formal yang memilih merumahkan, dan melakukan PHK terhadap pekerjanya. Total ada 1.010.579 orang pekerja yang terkena dampak ini. Rinciannya, 873.090 pekerja dari 17.224 perusahaan dirumahkan, sedangkan 137.489 pekerja di PHK dari 22.753 perusahaan. (kompas.com, 2020).

Desa Sukolilan merupakan sebuah desa yang berada di wilayah Kecamatan Patebon Kabupaten Kendal. Letak Desa Sukolilan sebelah utara berbatasan dengan Desa Bangunrejo, sebelah selatan berbatasan dengan Desa Jambearum, sebelah timur berbatasan dengan Desa Bugangin dan sebelah barat berbatasan dengan Desa Kumpulrejo. Desa Sukolilan berada di sebelah barat kota Kendal tepatnya pada jalan Jambearum arah utara dengan luas sebesar 140,911 $\mathrm{Ha}$ terletak. Desa Sukolilan terdiri dari 13 Rukun Tangga (RT) dari 2 Rukun Warga (RW) dengan jumlah penduduk Sukolilan sebanyak 1.702 jiwa. (BPS Kendal, 2017)

Masyarakat Desa Sukolilan memiliki mata pencaharian sebagai petani dan karyawan swasta yang bekerja di kawasan industri baik di Kendal maupun di Semarang. Rata-rata dalam rumah tangga yang bekerja adalah kepala keluarga sedangkan istri sebagai ibu rumah tangga. Penghasilan utama dalam keluarga diperoleh kepala keluarga sebesar gaji sesuai dengan Upah Minimum Regional 


\section{INTEGRITAS : Jurnal Pengabdian}

Vol 4, No 2, Desember 2020

ISSN 2580 - 7978 (cetak) ISSN 2615 - 0794 (online)

(UMR). Keseharian ibu-ibu rumah tangga selain melayani suami dan anak juga mengikuti berbagai kegiatan di masyarakat mulai dari kegiatan dalam Rukun Tangga, Rukun Warga, dan kegiatan lain di desa seperti pengajian rutin, pengajian umum dan arisan.

Dampak pandemi covid 19 juga dirasakan oleh masyarakat Desa Sukolilan. Dampak kondisi perekonomian rumah tangga sangat dirasakan bagi kepala keluarga yang harus harus dirumahkan sementara atau yang terpaksa harus menerima untuk diberhentikan (PHK) dari pekerjaannya. Hal ini tentunya berpengaruh dengan keuangan keluarga terhambat bahkan tidak sedikit yang keuangannya harus terhenti. Upaya untuk mengatasi dampak pandemi Covid 19 terhadap kondisi keuangan keluarga, maka perlu adanya upaya untuk penambahan penghasilan keluarga, salah satunya melalui kegiatan yang produktif dengan berwirausaha.

Salah satu upaya untuk dapat memulai berwirausaha yaitu dengan memberikan pengetahuan dan keterampilan berwirausaha. Pelatihan dirasakan perlu oleh tim pengabdian masyarakat Universitas Selamat Sri Kendal yang ditujukan untuk ibu-ibu rumah tangga. Hal ini dilakukan mengingat bahwa sebagian besar ibu rumah tangga di Desa Sukolilan memiliki cukup waktu luang yang dapat diisi dengan kegiatan produktif yang menghasilkan. Sangat disayangkan waktu luang yang dimiliki oleh ibu rumah tangga di Desa Sukolilan tidak dimanfaatkan dikarenakan belum mengetahui pentingnya berwirausaha, belum memiliki pengetahuan tentang kewirausahaan, dan belum dibekali keterampilan. Berdasarkan analisis situasi yang ada di Desa Sukolilan ini, melatarbelakangi untuk mengadakan kegiatan pengabdian masyarakat tentang peningkatan produktivitas melalui pelatihan kerajinan tangan di era pandemi. Karena dengan adanya pelatihan ini maka ibu rumah tangga akan menambah pengetahuan dan keterampilan warga Desa Sukolilan sehingga diharapkan di masa yang akan datang dapat diterapkan untuk meningkatkan produktivitas serta dapat menambah pendapatan keluarga guna meningkatkan kesejahteraan. 


\section{INTEGRITAS : Jurnal Pengabdian}

Vol 4, No 2, Desember 2020

ISSN 2580 - 7978 (cetak) ISSN 2615 - 0794 (online)

\section{METODE}

Sasaran kegiatan pengabdian masyarakat ini adalah warga masyarakat Desa Sukolilan Kecamatan Patebon Kabupaten Kendal. Kegiatan pengabdian ini diberikan khususnya untuk ibu-ibu rumah tangga di Desa Sukolilan RT 4 RW 1yang memiliki usia kisaran 30 tahun sampai 55 tahun, yang masih produktif dalam kegiatan sehari-hari. Melalui kegiatan ini diharapkan seluruh anggota dapat memperoleh pengetahuan kewirausahaan dan keterampilan kerajinan tangan.

Metode yang digunakan dalam kegiatan pengabdian ini yaitu berupa pelatihan yang melibatkan partisipasi dari masyarakat Desa Sukolilan khususnya ibu-ibu rumah tangga di Desa Sukolilan tentang peningkatan produktivitas melalui pelatihan kerajinan tangan di era pandemi. Rangkaian kegiatan pengabdian masyarakat yang dilakukan oleh tim pengabdian masyarakat Universitas Selamat Sri Kendal antara lain terdiri dari tahap perencanaan, tahap perijinan dan tahap pelaksanaan.

Pada tahap perencanaan, kegiatan pengabdian dengan tema peningkatan produktivitas melalui pelatihan kerajinan tangan di era pandemi di Desa Sukolilan Kecamatan Patebon Kabupaten Kendal dilakukan melalui beberapa tahapan kegiatan. Tahap pertama yaitu tim pengabdian masyarakat Universitas Selamat Sri Kendal berkoordinasi dengan Kepala Desa Sukolilan dan mengajukan kerjasama dengan mitra yaitu Kantor Balai Desa Sukolilan. Pengajuan kerjasama dengan mitra dilakukan melalui penandatanganan surat kerjasama antara tim pengabdian masyarakat Universitas Selamat Sri Kendal dengan Kepala Desa Sukolilan. Tahap kedua yaitu menyusun jadwal kegiatan pengabdian masyarakat melalui koordinasi dengan perwakilan ibu rumah tangga Desa Sukolilan Kecamatan Patebon Kabupaten Kendal. Tahap ketiga berkoordinasi dengan Kepala Desa Sukolilan dalam menentukan tempat pelaksanaan kegiatan. Tahap keempat yaitu merumuskan susunan acara kegiatan pengabdian masyarakat. Tahap kelima menyiapkan materi yang akan disampaikan untuk memberi pengetahuan terkait kewirausahaan. Tahap kelima menyiapkan peralatan dan bahan-bahan untuk kegiatan pelatihan. 


\section{INTEGRITAS : Jurnal Pengabdian}

Vol 4, No 2, Desember 2020

ISSN 2580 - 7978 (cetak) ISSN 2615-0794 (online)

Tahap setelah perencanaan yaitu tahap perijinan. Tahap perijinan berupa kerjasama terkait penggunaan lokasi pengabdian yang direncanakan. Tim melakukan koordinasi dengan Kepala Desa terkait perijinan penggunaan rumah salah satu warga sebagai tempat pengabdian di Desa Sukolilan RT 4 RW 1 Patebon Kendal dengan tetap memperhatikan protokol kesehatan seperti penggunaan masker dan hand sanitizer pada saat pelaksanaan kegiatan. Tim juga melakukan koordinasi dengan perwakilan salah satu ibu rumah tangga kaitannya dengan persiapan penggunaan rumahnya sebagai tempat kegiatan pengabdian.

Tahap terakhir yaitu tahap pelaksanaan. Kegiatan pengabdian masyarakat dilaksanakan pada hari Jumat, tanggal 30 Oktober 2020 di rumah perwakilan ibu rumah tangga Desa Sukolilan Kecamatan Patebon Kabupaten Kendal. Kegiatan yang dilakukan adalah peningkatan produktivitas melalui pelatihan kerajinan tangan di era pandemi. Pelaksanaan dilakukan dengan metode sosialisasi, tanya jawab, serta pendampingan pelatihan kerajinan tangan.

\section{HASIL DAN PEMBAHASAN}

Kegiatan pengabdian masyarakat tentang peningkatan produktivitas melalui pelatihan kerajinan tangan di era pandemi Desa Sukolilan Kecamatan Patebon Kabupaten Kendal dilaksanakan pada hari Jumat tanggl 30 Oktober 2020 bertempat di rumah perwakilan ibu rumah tangga yaitu rumah $\mathrm{Hj}$. Suwati Desa Sukolilan RT 4 RW 1 Patebon Kendal. Kegiatan ini berlangsung dengan lancar yang dihadiri oleh ibu-ibu rumah tangga Desa Sukolilan sebagai peserta pelatihan. Pengabdian masyarakat ini terdiri atas berbagai rangkaian kegiatan dengan tujuan memberikan wawasan tentang kewirausahaan dan keterampilan melalui pelatihan kerajinan tangan.

Kegiatan pertama diisi dengan penyampaian materi tentang kewirausahaan. Materi pelatihan dipresentasikan oleh narasumber meliputi pengertian kewirausahaan, menumbuhkan jiwa kewirausahaan, pentingnya berwirausaha, cara memulai berwirausaha, tahapan berwirausaha, keuntungan wirausahawan dan kelemahan wirausahawan. Kegiatan ini direspon baik oleh ibu-ibu rumah tangga Desa Sukolilan yang hadir. Peserta terlihat antusias dalam mendengarkan materi 


\section{INTEGRITAS : Jurnal Pengabdian}

Vol 4, No 2, Desember 2020

ISSN 2580 - 7978 (cetak) ISSN 2615 - 0794 (online)

yang disampikan oleh narasumber. Ibu-ibu rumah tangga menjadi paham tentang kewirausahan dan pentingnya berwirausaha. Pengetahuan ibu-ibu rumah tangga terkait kewirausahaan sebagai sasaran menjadi bertambah baik dan kesadaran mereka untuk memanfaatkan waktu luang untuk melakukan kegiatan yang produktif menjadi meningkat.

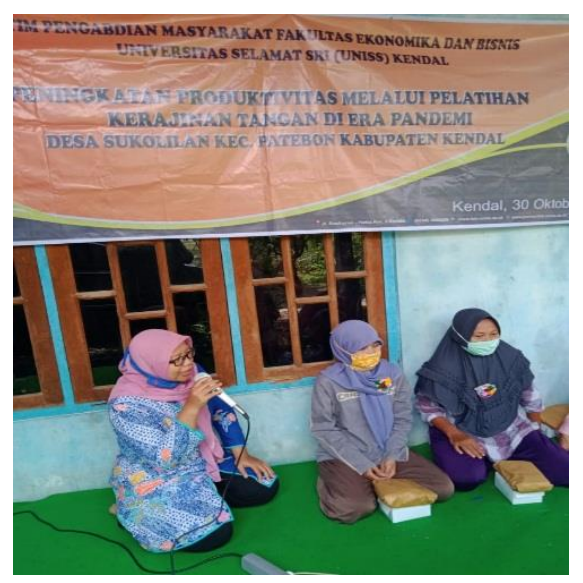

Gambar 1. Penyampaian materi tentang kewirausahaan

Kegiatan kedua diisi tentang penyampaian materi tentang kerajinan tangan. Kerajinan tangan yang dibahas oleh narasumber adalah kerajinan tangan berupa bros yang terbuat dari manik-manik. Materi pelatihan disampaikan oleh narasumber yang meliputi bahan-bahan yang dibutuhkan untuk membuat bros, alat-alat yang digunakan untuk membuat bros, dan tahapan-tahapan untuk membuat bros. Hasil kegiatan ini direspon baik oleh peserta yang terlihat dengan antusiasme peserta selama mendengarkan penjelasan dari narasumber. Hasil dari kegiatan ini ibu-ibu rumah tangga memiliki pengetahuan tentang kerajinan tangan khususnya bros yang terbuat dari manik-manik. 


\section{INTEGRITAS : Jurnal Pengabdian}

Vol 4, No 2, Desember 2020

ISSN 2580 - 7978 (cetak) ISSN 2615 - 0794 (online)

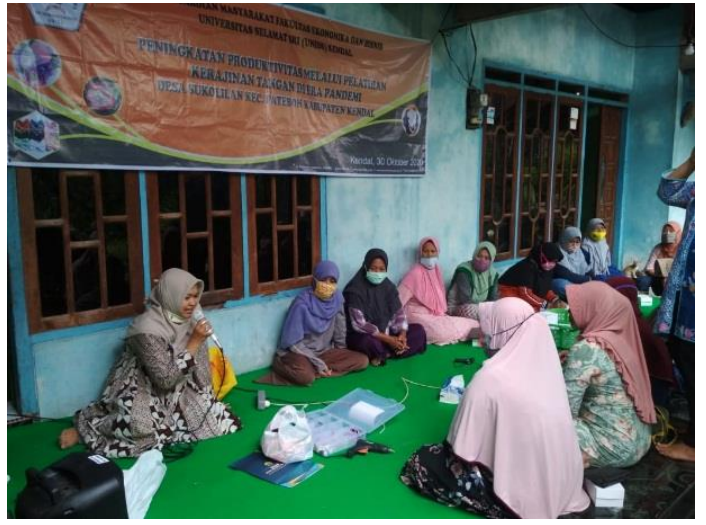

Gambar 2. Penyampaian materi tentang kerajinan tangan

Kegiatan ketiga diisi pelatihan membuat kerajinan tangan. Pelatihan diberikan oleh narasumber dengan cara demontrasi yang kemudian diikuti untuk dipraktekkan langsung oleh ibu-ibu rumah tangga. Kerajinan tangan yang dipraktekkan yaitu membuat bros dari manik-manik.

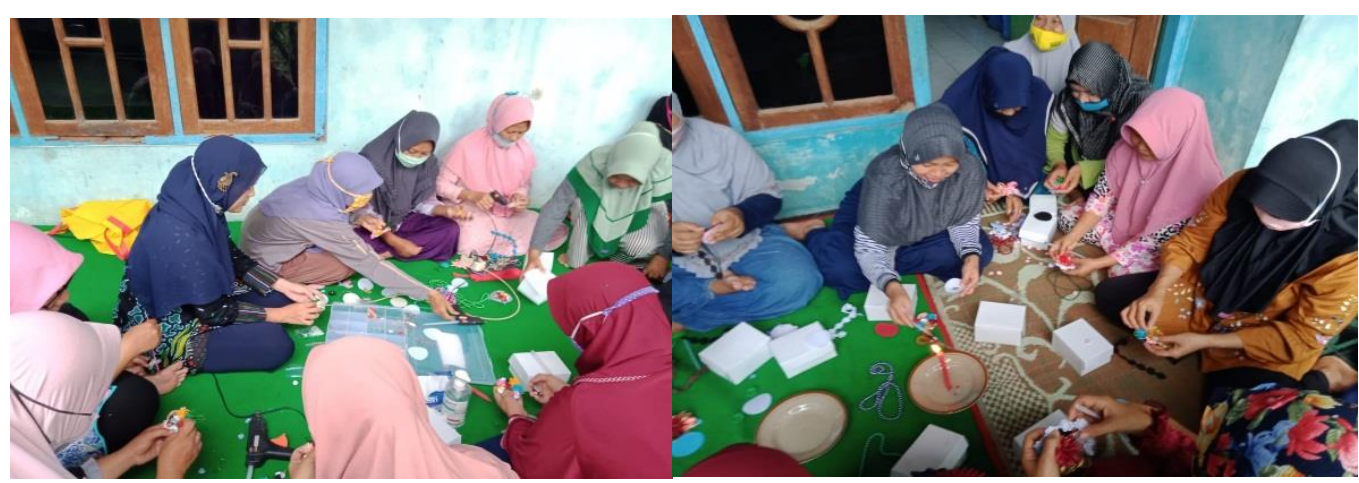

Gambar 3. Pelatihan membuat kerajinan tangan

Peserta pelatihan yaitu ibu-ibu rumah tangga antusias dan bersemangat dalam mempraktekkan membuat bros dari manik-manik. Hal ini terlihat dari banyaknya bros yang dihasilkan oleh ibu-ibu rumah tangga, yang bahkan setiap satu orang peserta bisa membuat tiga bros sesuai dengan kreativitas masingmasing ibu-ibu rumah tangga. Kegiatan pelatihan ini memunculkan ide-ide kreatif yang dikembangkan oleh peserta. Hal ini terlihat dari beragam bentuk bros yang dihasilkan oleh peserta. Hasil dari kegiatan pelatihan ini, ibu-ibu rumah tangga memiliki keterampilan untuk membuat kerajinan tangan khusunya bros yang terbuat dari manik-manik yang dapat dijadikan bekal untuk berwirausaha. 


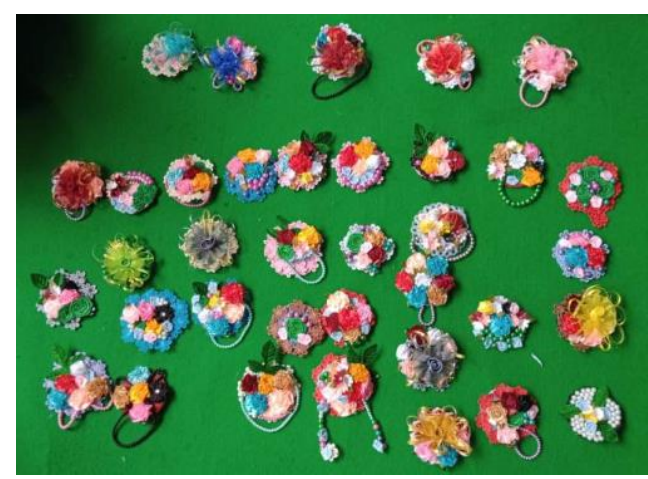

Gambar 4. Hasil pembuatan kerajinan tangan bros

Dari rangkaian kegiatan pengabdian masyarakat yang telah dilaksanakan, maka ibu-ibu rumah tangga Desa Sukolilan sebagai sasaran dalam kegiatan ini memperoleh hasil yaitu pengetahuan tentang tentang kewirausahaan dalam memanfaatkan waktu luang melalui kegiatan yang produktif, pengetahuan tentang kerajinan tangan khususnya bros yang terbuat dari manik-manik, dan keterampilan untuk membuat kerajinan tangan khusunya bros yang terbuat dari manik-manik. Selain itu ibu-ibu rumah tangga Desa Sukolilan termotivasi dengan adanya kegiatan pelatihan ini. Untuk mendorong keberlanjutan kegiatan pelatihan ini maka semua bahan dan peralatan diberikan kepada ibu-ibu rumah tangga sehingga mereka bisa mencoba dan mengembangkan lagi pembuatan bros dengan bahan manik-manik setelah lepas dari program pelatihan ini. Motivasi juga diberikan kepada ibu-ibu rumah tangga untuk memanfaatkan waktu luang dengan kegiatan produktif melalui berwirausaha salah satunya kerajinan tangan yang tidak hanya sebatas pembuatan bros dari manik-manik. Hal ini disambut dengan semangat oleh ibu-ibu rumah tangga Desa Sukolilan. Tidak sedikit bahkan yang berharap untuk dilakukan kegiatan pelatihan sejenis dengan jenis kerajinan tangan yang berbeda.

\section{KESIMPULAN}

Kegiatan pengabdian masyarakat melalui pelatihan dengan tema peningkatan produktivitas melalui pelatihan kerajinan tangan di era pandemi di Desa Sukolilan Kecamatan Patebon Kabupaten Kendal berisi tentang pemberian pengetahuan tentang kewirausahaan, kerajinan tangan dan pelatihan pembuatan 


\section{INTEGRITAS : Jurnal Pengabdian}

Vol 4, No 2, Desember 2020

ISSN 2580 - 7978 (cetak) ISSN 2615 - 0794 (online)

kerajinan tangan dengan metode ceramah, diskusi dan demonstrasi. Kegiatan ini merupakan salah satu usaha untuk mendorong ibu-ibu rumah tangga agar termotivasi dalam memulai berwirausaha. Hasil kegiatan ini berupa pengetahuan ibu-ibu rumah tangga terkait kewirausahaan, kerajinan tangan dan keterampilan untuk membuat kerajinan tangan. Pengetahuan dan keterampilan penting dalam memulai berwirausaha sehingga dapat diterapkan untuk meningkatkan produktivitas serta dapat menambah pendapatan keluarga guna meningkatkan kesejahteraan

\section{UCAPAN TERIMA KASIH}

Kami mengucapkan terima kasih kepada pihak-pihak yang berkontribusi sehingga pelaksanaan kegiatan pengabdian masyarakat dapat berjalan dengan lancar yaitu :

1. dr. Hj. Sulistiyowati, M.M selaku Rektor Universitas Selamat Sri.

2. Ageng Prasetyo, S.E., M.M. selaku Ketua Lembaga Penelitian dan Pengabdian Masyarakat (LP2M) Universitas Selamat Sri.

3. Mochammad Purnomo, S.E., M.M. selaku Dekan Fakultas Ekonomika dan Bisnis Universitas Selamat Sri.

4. Slamet Widiyanto selaku Kepala Desa Sukolilan Kecamatan Patebon Kabupaten Kendal.

5. Ibu-ibu RT 4 RW 1 Desa Sukolilan Kecamatan Patebon Kabupaten Kendal.

6. Rekan-rekan Dosen Fakultas Ekonomika dan Bisnis Universitas Selamat Sri.

\section{DAFTAR PUSTAKA}

Agustin, D. Susanti, W.D. (2020). Pembuatan Bros dari Bahan Manik dan Limbah Kawat untuk Pelatihan Wirausaha Ibu PKK Perumahan Sentra Alam Sidoarjo. Jurnal Pelayanan dan Pengabdian Masyarakat. 4(1). 27- 38

BPS. (2020). Data Kabupaten Kendal 2017. Online. Tersedia pada : https://kendalkab.bps.go.id/publication/2017/08/11/937f6b6e73b7f4d151 c2d9d6/kabupaten-kendal-dalam-angka-2017.html. 6 November 2020

Kendal, Kab (2020). Kondisi Geografis Kabupaten Kendal. Online. Tersedia pada : https://www.kendalkab.go.id/. 29 Oktober 2020. 
INTEGRITAS : Jurnal Pengabdian

Vol 4, No 2, Desember 2020

ISSN 2580 - 7978 (cetak) ISSN 2615 - 0794 (online)

Komite Penanganan Covid 19 dan Pemulihan Ekonomi Nasional. (2020). Kasus Covid 19 di Indonesia. Online. Tersedia pada : https://covid19.go.id/. 30 Oktober 2020

Kompas.com (2020). Perekonomian Indonesia Pasca Pandemi Covid 19. Tersedia pada:https://money.kompas.com/read/2020/05/10/091500226/perekonom ian-indonesia-pasca-pandemi-covid-19?page=all. 4 November 2020

Modjo, M. I. (2020). Memetakan Jalan Penguatan Ekonomi Pasca Pandemi. The Indonesian Journal of Development Planning. 4(2). 103-116

Sukolilan, Desa (2020). Profil Desa Sukolilan. Online. Tersedia pada : http://sukolilan.desa.id/public/menu/profil. 29 Oktober 2020 